\title{
Capybara (Hydrochoerus hydrochaeris) exposure to Rickettsia in the Federal District of Brazil, a non-endemic area for Brazilian spotted fever
}

\author{
Exposição de capivaras (Hydrochoerus hydrochaeris) à Rickettsia no Distrito \\ Federal, área não endêmica para febre maculosa brasileira
}

\begin{abstract}
Ana Paula Nunes de Quadros'; George Magno Sousa do Rêgo'; Thamiris Figueiredo da Silva'; Andréa de Moraes Carvalho'; Thiago Fernandes Martins²; Lina de Campos Binder2; Márcio Botelho de Castro; Paulo Sérgio Ribeiro de Mattos4; Marcelo Bahia Labruna2; Giane Regina Paludo1* (1)
'Laboratório de Patologia Clínica Veterinária, Faculdade de Agronomia e Veterinária - FAV, Universidade de Brasília - UnB, Brasília, DF, Brasil
${ }^{2}$ Departamento de Medicina Veterinária Preventiva e Saúde Animal, Faculdade de Medicina Veterinária e Zootecnia, Universidade de São Paulo - USP, São Paulo, SP, Brasil
'Laboratório de Patologia Veterinária, Faculdade de Agronomia e Veterinária - FAV, Universidade de Brasília - UnB, Brasília, DF, Brasi
${ }^{4}$ Laboratório de Sanidade Animal, Centro Nacional de Recursos Genéticos e Biotecnologia, Empresa Brasileira de Pesquisa Agropecuária - EMBRAPA, Brasília, DF, Brasil

How to cite: Quadros APN, Rêgo GMS, Silva TF, Carvalho AM, Martins TF, Binder LC, et al. Capybara (Hydrochoerus hydrochaeris) exposure to Rickettsia in the Federal District of Brazil, a non-endemic area for Brazilian spotted fever. Braz J Vet Parasitol 2021; 30(2): e028720. https://doi.org/10.1590/S1984-29612021035

\begin{abstract}
In this study, whole blood samples and ticks were collected from 57 capybaras in recreational areas in the Federal District, Brazil, aiming to investigate the presence of Rickettsia spp. using polymerase chain reaction (PCR) and indirect immunofluorescence (IFAT) assays. None of the capybara blood samples yielded rickettsial DNA by PCR. Among 55 capybara serum samples tested by IFAT, 53 (96.3\%) reacted to Rickettsia spp. Among these, 21 (39.6\%) identified the $R$. bellii antigen as the probable antigen involved in a homologous reaction (PAIHR), whereas 2 (3.8\%) identified the $R$. parkeri antigen. Ticks collected from capybaras were identified as 173 Amblyomma sculptum and 410 A. dubitatum, in addition to nine Amblyomma spp. larvae. A sample of 231 ticks was subjected to DNA extraction and PCR for Rickettsia species. None of 122 A. sculptum yielded rickettsial DNA. Molecular evidence of R. bellii was found in 25/108 (23.1\%) and of Rickettsia sp. strain Cooperi (R. parkeri-like agent) in 2/108 (1.9\%) of the $A$. dubitatum samples. These results suggest a greater exposure to $R$. bellii in these capybara populations, in addition to a more significant number of $A$. dubitatum, which might characterize the Federal District region as not endemic for Brazilian spotted fever.
\end{abstract}

Keywords: Arthropod Vectors, Family Caviidae, Rickettsiosis, Spotted fever, Brazilian Midwestern.

\section{Resumo}

O presente trabalho realizou a coleta de amostras de sangue total e carrapatos de 57 capivaras da região, com o intuito de pesquisar bactérias do gênero Rickettsia spp., a partir de métodos de diagnóstico molecular (PCR) e sorológicos (RIFI). Nenhuma amostra de sangue das capivaras foi positiva na PCR. Dentre as 55 amostras de soro testadas por RIFI, 53 (96,3\%) apresentaram soro-reação para Rickettsia spp. Dessas 53 amostras, 21 (39,6\%) demonstraram o antígeno de $R$. bellii como provável antígeno envolvido em reação homóloga (PAERH); e duas $(3,8 \%)$ demonstraram o antígeno de $R$. parkeri. Foram amostrados 173 carrapatos identificados como Amblyomma sculptum e 410 como Amblyomma dubitatum, além de nove larvas (Amblyomma spp.). Entre os carrapatos, 231 foram submetidos à extração de DNA e PCR para pesquisa de Rickettsia. Foram encontradas evidências moleculares de R. bellii em 25/108 (23,1\%) e Rickettsia sp. "strain" Cooperi em 2/108 (1,9\%) das amostras de A. dubitatum testadas.

Received December 10, 2020. Accepted March 22, 2021

*Corresponding author: Giane Regina Paludo. E-mail: giane@unb.br

This is an Open Access article distributed under the terms of the Creative Commons Attribution License, which permits unrestricted use distribution, and reproduction in any medium, provided the original work is properly cited. 
Os resultados sugerem uma maior exposição à $R$. bellii nas populações de capivaras da região, além de uma maior quantidade de carrapatos identificados como A. dubitatum. Isso pode estar relacionado ao que configura a região do Distrito Federal como não endêmica para a febre maculosa brasileira.

Palavras chave: Vetores artrópodes, Família Caviidae, Rickettsioses, febre maculosa, Centro-Oeste Brasileiro.

\section{Introduction}

The number of herds of capybaras (Hydrochoerus hydrochaeris) has increased in several recreational areas in the Federal District, Brazil, and cases of tick infestations on people who visit these places are commonly reported in the media (G1, 2017; Medeiros, 2018). Maintenance of tick populations can be directly associated with capybaras, which are considered primary hosts for these arthropods (Horta et al., 2004; Luz et al., 2019).

Pathogens of the genus Rickettsia (Rickettsiales: Rickettsiaceae) are Gram-negative obligate intracellular bacteria transmitted by arthropod vectors (Darby et al., 2007). Within this genus, the spotted fever group (SFG) includes zoonotic agents such as Rickettsia rickettsii and Rickettsia parkeri, which can cause acute febrile human illness, as is the case of the Brazilian Spotted Fever (BSF) and the Rocky Mountain Spotted Fever, caused by R. rickettsii (Pacheco et al., 2007). In Brazil, capybaras have been characterized as natural amplifying hosts of $R$. rickettsii for Amblyomma sculptum ticks, which are the most important vectors of $R$. rickettsii to humans in Brazil (Costa et al., 2019; Luz et al., 2019). The endemic areas of spotted fever in São Paulo state are those in which there is an explosive increase in free-living capybaras (Sousa et al., 2017). Thus, sanitary monitoring of populations of capybaras is essential for the control and maintenance of public health.

The Federal District of Brazil encompasses $5780 \mathrm{~km}^{2}$, of which $621.2 \mathrm{~km}^{2}$ comprises a large metropolitan area that includes Brasilia City and its satellite counties. According to the Brazilian Ministry of Health, between 2000 and 2019, only three non-fatal cases of BSF were reported in the Federal District; however, none of these cases were followed by proper epidemiological investigations. Besides, there are no published reports on the genus Rickettsia's pathogens in capybaras and ticks in the region.

The present study aimed to evaluate the occurrence of infection caused by Rickettsia using molecular and serological methods and hemogram and biochemical tests to analyze its consequences in capybaras.

\section{Materials and Methods}

\section{Capture and collection of biological samples}

Capybara capture and handling were carried out under the SISBIO license number 43798-1, and with the approval of the Ethics Committee for the Use of Animals (CEUA) of the University of Brasilia registered under the protocol number 20/2019.

In all seasons, capybaras from five different flooded areas near recreational places in the region were captured:

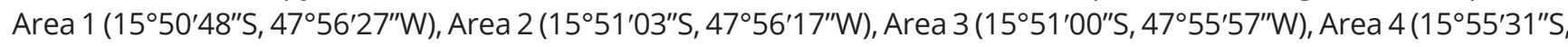
$\left.48^{\circ} 02^{\prime} 59^{\prime \prime} \mathrm{W}\right)$, and Area $5\left(15^{\circ} 47^{\prime} 30^{\prime \prime} \mathrm{S}, 47^{\circ} 47^{\prime} 49^{\prime \prime} \mathrm{W}\right)$. The animals were conditioned by feeding with fruits, grains, and leaves to enter the restraint cages in which they were subjected to sedation and physical restraint for the collection of biological samples. The classification of animals between young and adults was performed based on the estimated visualization of the capybaras' size (Ojasti, 1973). The five areas were chosen due to the higher numbers of capybara herds previously visualized.

The chemical restraint protocol was performed using intramuscularly anesthetic darts, containing a combination of xylazine $(0.5 \mathrm{mg} / \mathrm{mg} / \mathrm{kg})$ and ketamine $(2.0 \mathrm{mg} / \mathrm{mg} / \mathrm{kg})$. After harvesting, a dose of yohimbine $(0.1 \mathrm{mg} / \mathrm{mg} / \mathrm{kg})$ was applied to reverse the applied xylazine and reduce the time for anesthetic recovery. Looking to minimize the risk of accidents, the animals were handled individually, monitored, and released only after the total recovery of any effect caused by the dissociative drug.

Blood samples were collected by puncture of the cephalic or femoral vein, packed in tubes with no additives and anticoagulant (EDTA), and kept at $4-8{ }^{\circ} \mathrm{C}$ until transport to the laboratory.

All ticks found during a time of 5 min per animal were removed directly from the capybaras' skin. The ticks were stored in isopropyl alcohol for asepsis and conservation until species identification. 


\section{Tick identification}

Ticks were identified by species, sex, and development stage, separated into larvae, nymphs, adult males, and adult females. The species were classified according to the literature (Barros-Battesti et al., 2006; Martins et al., 2010, 2016). The larvae were identified only to the genus level.

\section{Hematology and biochemical tests}

Hemograms and biochemical tests on capybara blood samples were performed at the Veterinary Clinical Pathology Laboratory of the College of Agronomy and Veterinary Medicine (FAV) of the University of Brasilia $(\mathrm{UnB})$, within a maximum time of $2 \mathrm{~h}$ after harvesting. Blood cell count was determined by manual counting in a hemocytometer, as previously described (Weiser, 2012). Hemoglobin concentration was measured on a BIO 2000 (BIOPLUS $®$ ) semi-automatic spectrophotometer.

The hematocrit was determined using the microhematocrit technique, and the amount of total plasma proteins (TPP) was determined using the same capillary tube by refractometry. The mean corpuscular volume (MCV) and mean corpuscular hemoglobin concentration (MCHC) were determined by standard calculation. Whole blood smears were prepared and stained with rapid panoptic (Laborclin $\left.{ }^{\circledR}\right)$ to perform the leukocyte differential, morphological observation of blood cells, hemoparasite search, and platelet estimation.

Blood serum was obtained by centrifuging blood samples without EDTA. These samples were used to determine serum concentrations of total proteins, albumin, alanine aminotransferase (ALT), aspartate aminotransferase (AST), gamma-glutamyltransferase (GGT), urea, creatinine, and alkaline phosphatase in an automatic biochemical analyzer Cobas - C111 (Roche®).

\section{Molecular assays}

Polymerase chain reaction (PCR) tests were performed in the Laboratories of Molecular Microbiology and Pathology, College of Agronomy and Veterinary Medicine (FAV), University of Brasilia (UnB) and in the Department of Preventive Medicine and Animal Health, Faculty of Veterinary Medicine and Animal Science, University of São Paulo (USP). The DNA of the blood samples was extracted using the Illustra Blood Genomicprep Kit (GE Health Care ${ }^{\circledR}$ ) according to the manufacturer's guidelines. Among the sampled ticks, a total of 231 specimens (four to five per animal) were individually submitted to DNA extraction. Whenever was possible, these samples included $50 \%$ of each tick species from all harvested areas. DNA extraction was performed by the guanidine isothiocyanate and phenol-chloroform protocol, according to Sangioni et al. (2005). The extracted DNA samples were subsequently stored at $-20^{\circ} \mathrm{C}$ until PCR assays.

All DNA samples extracted from whole blood were subjected to PCR to confirm the gene encoding of the enzyme glyceraldehyde-3 phosphate dehydrogenase (GAPDH). To assess the integrity of the extracted DNA and the absence of PCR inhibitors, the oligonucleotides F- 5' CCT TCA TTG ACC TCA ACT ACA T 3' and R- 5' CCA AAG TTG TCA TGG ATG ACC 3' were used (Birkenheuer et al., 2017). For each sample, a mixture of $25 \mu \mathrm{L}$ was prepared to contain $1.0 \mu \mathrm{mol} / \mu \mathrm{L}$ of each oligonucleotide $(10 \mathrm{pmol}), 1 \times$ Taq polymerase buffer (Invitrogen $\AA), 1.5 \mathrm{mM} \mathrm{MgCl}{ }_{2}$ $0.2 \mathrm{mM}$ dNTP (Invitrogen $\left.{ }^{\circledR}\right), 1 \mathrm{U}$ of Taq polymerase (Invitrogen $\left.{ }^{\circledR}\right)$, and approximately $2.0 \mathrm{ng}$ of extracted DNA. The PCR assays were performed following the protocol on the thermocycler: one initial denaturation cycle (5 min, $\left.95^{\circ} \mathrm{C}\right)$, followed by 40 cycles of denaturation $\left(1 \mathrm{~min}, 95^{\circ} \mathrm{C}\right)$, annealing $\left(1 \mathrm{~min}, 53^{\circ} \mathrm{C}\right)$, and extension $\left(1 \mathrm{~min}, 72^{\circ} \mathrm{C}\right)$, and a final extension cycle $\left(5 \mathrm{~min}, 72^{\circ} \mathrm{C}\right)$.

All samples of DNA extracted from ticks were submitted to PCR to confirm the mitochondrial gene 16S rRNA specific for ticks, using the oligonucleotides TK-F 5' CTG CTC AAT GAT TTT TTA AAT TGC GG 3' and TK-R 5' ACG CTG TTA TCC CTA GAG 3' (Halos et al., 2004). In this case, for each sample, a mixture of $25 \mu \mathrm{L}$ was prepared to contain $1.0 \mu \mathrm{mol} / \mu \mathrm{L}$ of each oligonucleotide $(10 \mathrm{pmol}), 1 \times$ Taq polymerase buffer (Invitrogen $\left.{ }^{\circledR}\right), 1.0 \mathrm{mM} \mathrm{MgCl}, 0.2 \mathrm{mM}$ dNTP (Invitrogen $\left.{ }^{\circledR}\right), 1 \mathrm{U}$ of Taq polymerase (Invitrogen $\left.{ }^{\circledR}\right)$, and approximately $2.0 \mathrm{ng}$ of extracted DNA. The PCR assays were performed following the protocol on the thermocycler: one initial denaturation cycle $\left(8 \mathrm{~min}, 94^{\circ} \mathrm{C}\right)$, followed by 10 cycles of denaturation $\left(1 \mathrm{~min}, 92^{\circ} \mathrm{C}\right)$, annealing $\left(1 \mathrm{~min}, 48^{\circ} \mathrm{C}\right)$, and extension $\left(1 \mathrm{~min} 30 \mathrm{~s}, 72^{\circ} \mathrm{C}\right)$. And 32 cycles of denaturation $\left(1 \mathrm{~min}, 92^{\circ} \mathrm{C}\right)$, annealing $\left(1 \mathrm{~min}, 54^{\circ} \mathrm{C}\right)$, extension $\left(1 \mathrm{~min} 30 \mathrm{~s} 72^{\circ} \mathrm{C}\right)$, and a final extension step $\left(10 \min 72^{\circ} \mathrm{C}\right)$.

After confirming the quality of the extractions, all DNA samples were subjected to PCR in duplicate using the oligonucleotides CS78-5' GCA AGT ATC GGT GAG GAT GTA AT 3' and CS323-5' G CTT CCT TAA AAT TCA ATA AAT CAG 
GAT 3', which amplify a 401 bp fragment of the citrate synthase gene (gltA) of Rickettsia spp. (Labruna et al., 2004). For each sample, a mixture of $25 \mu \mathrm{L}$ was prepared to contain $1.0 \mu \mathrm{mol} / \mu \mathrm{L}$ of each oligonucleotide $(10 \mathrm{pmol}), 1 \times$ Taq polymerase buffer (Invitrogen $\left.{ }^{\circledR}\right), 0.75 \mathrm{mM} \mathrm{MgCl}, 0.2 \mathrm{mM}$ dNTP (Invitrogen $®$ ), $1 \mathrm{U}$ of Taq polymerase (Invitrogen ${ }^{\circledR}$ ), and $2.0 \mathrm{ng}$ of extracted DNA. These PCR assays were performed following the protocol on the thermal cycler: one denaturation cycle $\left(5 \mathrm{~min}, 94^{\circ} \mathrm{C}\right)$, followed by 40 cycles of denaturation $\left(1 \mathrm{~min}, 94^{\circ} \mathrm{C}\right)$, annealing $\left(1 \mathrm{~min}, 56^{\circ} \mathrm{C}\right)$, and extension $\left(1 \mathrm{~min}, 72^{\circ} \mathrm{C}\right)$, and a final extension cycle $\left(5 \mathrm{~min}, 72^{\circ} \mathrm{C}\right)$. Samples yielding amplicons by this PCR assay were tested in a heminested PCR protocol targeting the rickettsial ompA gene, specific for spotted fever group agents. For this purpose, the first reaction used the oligonucleotides Rr190.70F (5'-ATG GCG AAT ATT TCT CCA AAA-3') and Rr190.701R (5'- GTT CCG TTA ATG GCA GCA TCT-3'), which amplify a 631 bp fragment, and the second reaction used oligonucleotides Rr190.70F and Rr190.602R (5'-AGT GCA GCA TTC GCT CCC CCT-3'), which amplify a $532 \mathrm{bp}$ fragment of ompA gene, as previously reported (Eremeeva et al., 2006). Positive and negative controls were used for each reaction; samples containing $R$. rickettsii DNA were used as a positive control and Milli-Q ultrapure water as a negative control.

Besides, tick DNA samples were also tested by a Rickettsia bellii-specific PCR assay, using the oligonucleotides 5'-ATC CTG ATT TGC TGA ATT TTT T-3' (forward) and 5'-TGC AAT ACC AGT ACT GAC G-3' (reverse), which amplify a 338 bp fragment of $g / t A$ of only $R$. bellii, as previously reported (Szabó et al., 2013; Hecht et al., 2016).

All PCR reactions were performed on a Biorad MyCyclerTM Thermal Cycler (Bio-Rad Laboratories, Hercules, CA). The amplification products were separated by electrophoresis on a $2 \%$ agarose gel, stained in ethidium bromide (Vetec Sigma-Aldrich ${ }^{\circledR}$, St Louis, MO), and visualized on an ultraviolet transilluminator (UV transilluminator ${ }^{\circledR}$, UVP LLC, Upland, 32 CA).

PCR amplicons of the expected size were purified using the NucleoSpin $®$ Kit Gel and PCR Clean-up (MachereyNagel( ), according to the manufacturer's recommendations, and sent for genetic sequencing. The sequencing was carried out at Resource Center Biological Sciences and Genomic Biology (CREBIO) from UNESP in Jaboticabal, using the Sanger method, in an automatic sequencer with 96 capillaries ABI 3730 XL DNA Analyzer (Applied Biosystems, Foster City, California (CA)). Obtained sequences were then subjected to BLAST analyses to infer the closest identities with organisms available in GenBank.

\section{Serological assays}

The serological tests consisted of performing indirect immunofluorescence (IFT) and were carried out at the Department of Preventive Medicine and Animal Health of the Faculty of Veterinary Medicine and Animal Science at the University of São Paulo (USP). Blood samples from capybaras were separated by centrifugation and stored at $-20^{\circ} \mathrm{C}$ until IFT assays were performed. For the tests, slides fixed with the antigen of five Rickettsia species were used: $R$. rickettsii, $R$. bellii, $R$. parkeri, $R$. amblyommatis, and $R$. rhipicephali. In addition to the serum samples from the study capybaras, negative and positive controls were impregnated in each slide from reactive and non-reactive serum samples from previously tested capybaras (Souza et al., 2009). The slides were incubated with fluorescein isothiocyanate linked to the capybara anti-IgG, produced at the Zoonosis Control Center (CCZ) in São Paulo, SP. The initial dilution was 1:64. The final titration reactions in each of the Rickettsia species tested were determined for each serum sample. The antigen for the tested species that showed antibody titers four times greater than the other antigens' titers was considered the possible antigen involved in a homologous reaction.

\section{Results}

Fifty-seven free-living capybaras were captured to collect biological samples: 15 males ( 13 adults and two young) and 42 females ( 35 adults and seven young). Regarding the sampled regions, one adult male and sixteen females (nine adults and seven young) were captured in Area 1; four adult females and seven males (one young and six adults) in Area 2; five adult females and seven males (one young and six adults) in Area 3; two adult females in Area 4; and 15 adult females were captured in Area 5.

The PCR assays targeting the rickettsial gltA gene of Rickettsia spp. did not amplify any DNA fragments in the 57 genomic DNA samples extracted from the capybaras' blood. All these DNA samples yielded amplicons by the GAPDH PCR assay, confirming successful DNA extraction from capybara blood.

Among the serum samples collected, two were insufficient to perform the immunoassays. Of the 55 samples tested using IFT, $53(96.3 \%)$ reacted to at least one of the five Rickettsia species. Twenty-one samples (39.6\%), 
including capybaras from all sampled areas, identified the $R$. bellii antigen as a probable antigen involved in a homologous reaction (PAIHR), with titration at least four times higher than the antigens of the other tested species. Two samples (3.8\%) from capybaras of Area 5, near Paranoá lake, identified the R. parkeri antigen as PAIHR (Table 1).

Table 1. Results of immunoassay analyses of serological samples from capybaras for Rickettsia spp.

\begin{tabular}{|c|c|c|c|c|c|c|c|c|}
\hline \multicolumn{3}{|c|}{ Capybara } & \multicolumn{6}{|c|}{ Final tritation point for the respective Rickettsia spp. } \\
\hline $\mathbf{N}^{\circ}$ & Age & Sex & R. rickettsii & R. parkeri & R. amblyommatis & R. rhipicephali & R. bellii & PAIHR \\
\hline 1 & Adult & Female & $<64$ & 128 & $<64$ & 64 & 128 & $?$ \\
\hline 2 & Adult & Female & 256 & 256 & 256 & 512 & 256 & $?$ \\
\hline 3 & Adult & Female & $<64$ & 64 & $<64$ & 64 & 256 & R. belli \\
\hline 4 & Adult & Female & $<64$ & 64 & $<64$ & 64 & 256 & R. belli \\
\hline 5 & Adult & Female & 128 & 128 & 128 & 256 & 512 & $?$ \\
\hline 6 & Adult & Female & $<64$ & 128 & 64 & 128 & 256 & $?$ \\
\hline 7 & Adult & Female & 64 & 64 & 64 & 64 & 128 & $?$ \\
\hline 8 & Adult & Female & 128 & $<64$ & 64 & 128 & 256 & $?$ \\
\hline 9 & Adult & Female & $<64$ & 128 & 64 & $<64$ & 128 & $?$ \\
\hline 10 & Adult & Male & $<64$ & 128 & 64 & $<64$ & 256 & $?$ \\
\hline 11 & Adult & Female & $<64$ & 64 & 64 & $<64$ & 256 & R. belli \\
\hline 12 & Adult & Female & $<64$ & 128 & 64 & 128 & 512 & R. bellit \\
\hline 13 & Adult & Male & $<64$ & $<64$ & 64 & 64 & 512 & R. belli \\
\hline 14 & Young & Female & $<64$ & $<64$ & $<64$ & 64 & 128 & $?$ \\
\hline 15 & Young & Female & $<64$ & $<64$ & $<64$ & 64 & 256 & R. bellit \\
\hline 16 & Adult & Male & 128 & $<64$ & $<64$ & 64 & 512 & R. belli \\
\hline 17 & Young & Female & 128 & $<64$ & $<64$ & $<64$ & 512 & R. bellit \\
\hline 18 & Young & Male & 64 & $<64$ & $<64$ & 128 & 512 & R. belli \\
\hline 19 & Young & Female & 128 & $<64$ & $<64$ & 128 & 512 & R. belli \\
\hline 20 & Young & Male & 64 & $<64$ & $<64$ & 64 & 512 & R. bellit \\
\hline 21 & Adult & Male & 64 & $<64$ & $<64$ & 128 & 256 & $?$ \\
\hline 22 & Young & Female & $<64$ & $<64$ & $<64$ & $<64$ & 128 & R. belli \\
\hline 23 & Young & Female & 256 & $<64$ & $<64$ & 128 & 256 & $?$ \\
\hline 24 & Adult & Male & 64 & 128 & $<64$ & 128 & 128 & $?$ \\
\hline 25 & Adult & Female & $<64$ & $<64$ & $<64$ & $<64$ & 256 & R. bellit \\
\hline 26 & Adult & Female & $<64$ & $<64$ & $<64$ & $<64$ & 128 & R. belli \\
\hline 27 & Adult & Male & $<64$ & $<64$ & $<64$ & $<64$ & 256 & R. belli \\
\hline 28 & Adult & Female & $<64$ & $<64$ & $<64$ & $<64$ & $<64$ & - \\
\hline 29 & Adult & Female & $<64$ & $<64$ & $<64$ & $<64$ & $<64$ & - \\
\hline 30 & Young & Female & $<64$ & $<64$ & $<64$ & $<64$ & 64 & R. bellit \\
\hline 31 & Adult & Female & $<64$ & 64 & $<64$ & $<64$ & 128 & $?$ \\
\hline
\end{tabular}

PAIHR: Probable antigen involved in a homologous reaction; (?): It was not possible to establish a probable antigen; (-): No serum reaction for any antigen. 
Table 1. Continued...

\begin{tabular}{|c|c|c|c|c|c|c|c|c|}
\hline \multicolumn{3}{|c|}{ Capybara } & \multicolumn{6}{|c|}{ Final tritation point for the respective Rickettsia spp. } \\
\hline $\mathbf{N}^{\circ}$ & Age & Sex & R. rickettsii & R. parkeri & R. amblyommatis & R. rhipicephali & R. bellii & PAIHR \\
\hline 32 & Adult & Male & $<64$ & $<64$ & $<64$ & $<64$ & 128 & R. bellii \\
\hline 33 & Adult & Female & $<64$ & $<64$ & $<64$ & 64 & 64 & ? \\
\hline 34 & Adult & Male & $<64$ & $<64$ & $<64$ & 64 & 64 & $?$ \\
\hline 35 & Adult & Male & $<64$ & 64 & $<64$ & $<64$ & 128 & $?$ \\
\hline 36 & Adult & Female & $<64$ & $<64$ & $<64$ & $<64$ & 128 & R. bellii \\
\hline 37 & Adult & Female & 64 & $<64$ & $<64$ & $<64$ & 512 & R. bellii \\
\hline 38 & Adult & Male & 64 & $<64$ & $<64$ & $<64$ & 128 & $?$ \\
\hline 39 & Adult & Male & 64 & $<64$ & $<64$ & $<64$ & 128 & $?$ \\
\hline 40 & Adult & Female & $<64$ & 128 & $<64$ & $<64$ & 256 & $?$ \\
\hline 41 & Adult & Male & $<64$ & 64 & $<64$ & $<64$ & 256 & R. bellii \\
\hline 42 & Adult & Female & 128 & 128 & $<64$ & 64 & 256 & $?$ \\
\hline 43 & Adult & Female & $<64$ & 256 & $<64$ & $<64$ & 128 & $?$ \\
\hline 44 & Adult & Female & 64 & 512 & $<64$ & $<64$ & 512 & $?$ \\
\hline 45 & Adult & Female & 64 & 256 & 128 & $<64$ & 64 & $?$ \\
\hline 46 & Adult & Female & 64 & $<64$ & $<64$ & $<64$ & 256 & R. bellii \\
\hline 47 & Adult & Female & 128 & 128 & $<64$ & 64 & 256 & $?$ \\
\hline 48 & Adult & Female & $<64$ & $<64$ & $<64$ & $<64$ & 64 & $?$ \\
\hline 49 & Adult & Female & 128 & 128 & 64 & $<64$ & 128 & $?$ \\
\hline 50 & Adult & Female & 128 & 256 & 64 & $<64$ & 256 & $?$ \\
\hline 51 & Adult & Female & 64 & 128 & $<64$ & 64 & 256 & $?$ \\
\hline 52 & Adult & Female & $<64$ & 512 & $<64$ & $<64$ & 128 & R. parkeri \\
\hline 53 & Adult & Female & 64 & 512 & 128 & 64 & 128 & R. parkeri \\
\hline 54 & Adult & Female & $<64$ & 64 & $<64$ & $<64$ & 64 & $?$ \\
\hline 55 & Adult & Female & 128 & 64 & $<64$ & 128 & 128 & $?$ \\
\hline
\end{tabular}

PAIHR: Probable antigen involved in a homologous reaction; (?): It was not possible to establish a probable antigen; (-): No serum reaction for any antigen.

The results of the hemogram and biochemical tests performed for all capybaras were within the reference range for the species (data not shown). No intracytoplasmic inclusions characteristic of hemoparasites were found in any blood smear. The capybaras examined in the present study did not demonstrate any visible clinical abnormalities.

Tick infestations were visually detected in all 57 capybaras, from which a total of 592 ticks were collected. These were identified as 173 Amblyomma sculptum (89 males, 45 females, and 39 nymphs), 410 A. dubitatum (184 males, 57 females, and 169 nymphs), and nine larvae of Amblyomma spp. DNA extraction was performed on 231 ticks, 122 A. sculptum ( 77 males, 33 females, and 12 nymphs), 108 A. dubitatum (33 males, 29 females, and 46 nymphs), and one larva of Amblyommma sp. As most of A. dubitatum (341) were from Area 5, only 47 from this area were randomly submitted to DNA extraction and PCR to maintain the proportion of ticks analyzed among the five areas (Table 2). From these samples, the only one did not yield amplicons by the PCR assay targeting the tick 16S rRNA gene; therefore, it was discarded from the study.

The PCR assays targeting the rickettsial gltA gene of Rickettsia spp. yielded amplicon in one nymph and one female of $A$. dubitatum, collected from two adult female capybaras captured in Area 5, near Paranoá Lake. These same tick samples also yielded amplicon by the ompA PCR assay. PCR products of these two ticks were sequenced 
Table 2. Number of ticks collected from capybaras according to the stage, taxonomic classification, area, and the number of ticks tested by polymerase chain reaction (PCR).

\begin{tabular}{|c|c|c|c|c|c|c|}
\hline \multirow{3}{*}{ Stage } & \multicolumn{6}{|c|}{ Taxonomic identification } \\
\hline & \multicolumn{2}{|c|}{ Amblyomma sculptum } & \multicolumn{2}{|c|}{ Amblyomma dubitatum } & \multicolumn{2}{|c|}{ Amblyomma spp. } \\
\hline & Total & PCR & Total & PCR & Total & PCR \\
\hline Larva & 0 & 0 & 0 & 0 & 9 & 1 \\
\hline Nymph & 39 & 12 & 169 & 46 & 0 & 0 \\
\hline Adult Male & 89 & 77 & 184 & 33 & 0 & 0 \\
\hline Adult Female & 45 & 33 & 57 & 29 & 0 & 0 \\
\hline Total & 173 & 122 & 410 & 108 & 9 & 1 \\
\hline Area 1 & 41 & 40 & 27 & 25 & 0 & 0 \\
\hline Area 2 & 35 & 34 & 20 & 17 & 1 & 0 \\
\hline Area 3 & 31 & 27 & 22 & 19 & 0 & 0 \\
\hline Area 4 & 11 & 9 & 0 & 0 & 0 & 0 \\
\hline Area 5 & 55 & 12 & 341 & 47 & 8 & 1 \\
\hline
\end{tabular}

showing to be identical to each other for each of the two rickettsial genes. By BLAST analyses (www.ncbi.nlm. nih.gov/blast), the consensus g/tA sequence (302 bp) was 100\% identical to several Rickettsia species, including R. parkeri (CP040325), R. sibirica (KM288711), R. africae (HQ335126), in addition to several uncharacterized Rickettsia species; e.g., Rickettsia sp. strain Cooperi (AY362704). The consensus ompA sequence (349 bp) was 100\% identical to Rickettsia sp. strain Cooperi from Brazil (AY362706) and Argentina (KM116017). The gltA and ompA partial sequences generated in the present study have been deposited in GenBank under accession numbers MW345252 and MW345253.

The $R$. bellii-specific PCR did not yield amplicon from any A. sculptum tick. However, 25 A. dubitatum ticks (seven males, nine females, and nine nymphs) yielded an amplicon of the expected size by this assay, indicating the presence of $R$. bellii DNA in these ticks. To confirm such findings, amplicons from five ticks (those with the most visible bands in agarose gel) were sequenced, yielding a consensus gltA sequence (297 bp) $100 \%$ identical to several $R$. bellii sequences from GenBank, including the type strain RML369- $C^{\top}$ (CP000087).

\section{Discussion}

According to official data, the Federal District is considered a non-endemic area for BSF (Brasil, 2019a, b). However, several groups of capybaras (H. hydrochaeris) circulate freely in recreational areas, such as parks and regions surrounding Paranoá Lake, in Brazil's capital. Also, cases of tick infestations on children and adults who visit these places are reported yearly on local news. These cases are directly associated with the presence of capybaras, but no studies reporting the health status of animals of this species in the region have yet been published (G1, 2017; Medeiros, 2018). Some of these places were used for biological sample collection in the present study.

The PCR assay targeting the genus Rickettsia did not yield amplicons from any of the whole blood samples collected from the capybaras. The detection of Rickettsia spp. in vertebrate hosts' blood tissue is considered rare in the literature, including for capybaras, when experimentally infected with R. rickettsii (Souza et al., 2009). This finding stems from the fact that rickettsiae have endothelial cells as their primary target and, after the first contact with the host, remain in the bloodstream for short periods, migrating quickly to the tissues, which results in undetectable concentrations in molecular assays from blood samples (La Scola \& Raoult, 1997; Horta et al., 2007; Souza et al., 2009; Levin et al., 2016).

Despite the negative PCR results, $96 \%$ of the capybara samples (Table 1) showed serum reaction in the IFT assays. It should be noted that all species of Rickettsia spp. have common membrane antigens that can crossreact with antibodies present in the serum of the animals tested (La Scola \& Raoult, 1997). Therefore, dilution at higher titers was necessary to detect possible antigens involved in the reaction. Even at higher titrations, 53 of the 
samples were sera reactive for several genus Rickettsia species (R. rickettsii, R. parkeri, R. bellii, R. rhipicephali, and R. amblyommatis), making it impossible to detect PAlHR.

In samples of capybaras in which PAIHR determination was possible, serological tests showed $R$. bellii (39.6\%) and R. parkeri (3.8\%) as PAIHR. These results were lower than those of Pacheco et al. (2007), who demonstrated serological evidence of $R$. bellii (68.5\%) and R. parkeri (34.2\%) in capybaras in non-endemic regions of São Paulo. In addition to the diagnosis in $A$. dubitatum, serological evidence of bacteria of the two species found in other domestic animals such as dogs and horses in the state of São Paulo has also been reported (Horta et al., 2004; Labruna et al., 2004; Pacheco et al., 2007). It is worth mentioning that the present work is the first report of seroreactive capybaras for these bacterial species in the Federal District region.

The more significant detection (39.6\%) of antigen for $R$. bellii can determine this species as the probable agent with greater circulation in Federal District's capybara populations. In a BSF-endemic area of São Paulo, serological studies carried out on ten capybaras demonstrated the antigen for R. rickettsii as PAIHR in $80 \%$ of the sampled animals, whereas in the other $20 \%$, it was not possible to determine the possible species involved (Costa et al., 2019). Despite having a considerably smaller sample population, these results differ from those of the present study, which did not detect any sample with PAIHR for R. rickettsii; this may be related to the fact that the Federal District constitutes a non-endemic area for BSF.

On the other hand, R. parkeri, found in 3.8\% of the serologically tested capybaras, belongs to the SFG and has a pathogenic potential for humans (Paddock et al., 2004; Venzal et al., 2004). However, no case of death from an infection related to this species has yet been reported, characterized by moderate clinical manifestations compared to those caused by $R$. rickettsii (Paddock et al., 2004; Silveira et al., 2007). It is important to note, however, that in the routine diagnosis of BSF in humans, most serological tests have been using only the antigen for $R$. rickettsii, which may miss cases of infection by R. parkeri or other species of the genus in humans (Silveira et al., 2007).

No clinical or laboratory abnormalities were found in the present study. Characteristically in humans and guinea pigs, laboratory changes caused by rickettsiosis are generally nonspecific and may present moderate anemia, thrombocytopenia, mild leukopenia, hyponatremia, and possible changes in biochemical markers of renal dysfunction and liver enzymes (Parola et al., 2005). It is worth mentioning that the formation of antibodies against bacteria of the genus is directly associated with previous contact with the agents in question, but this does not mean that they are causing a disease (rickettsiosis). Besides, it is impossible to determine the time exposure nor whether there was the complete physiological recovery in the animals. The hematological results were similar to those previously reported for capybaras experimentally infected by $R$. rickettsii and uninfected capybaras (Arouca et al., 2000; Madella et al., 2006; Souza et al., 2009).

The findings on the tick species $A$. sculptum and $A$. dubitatum in the present study are compatible with previous studies that reported co-infestations and characterized capybaras as the primary hosts of both species arthropods (Labruna et al., 2007; Luz et al., 2019). Both species can also parasitize humans and other animal species, contributing to the circulation of possible rickettsiosis in different animal populations (Labruna et al., 2007; Brites-Neto et al., 2018).

We found molecular evidence for the presence of two Rickettsia species infecting A. dubitatum: $R$. bellii as the prevailing agent, found in $23.1 \%$ (25/108) of the tested specimens, and Rickettsia sp. strain Cooperi, in only $1.9 \%$ (2/108) of the $A$. dubitatum ticks. These findings are similar to those reported by Labruna et al. (2004), who found R. bellii and Rickettsia sp. strain Cooperi infecting $40 \%$ and $7.5 \%$ of the A. dubitatum ticks in an area of the state of São Paulo. Rickettsia sp. strain Cooperi is a R. parkeri-like agent reported infecting A. dubitatum ticks in one area of Brazil (Labruna et al., 2004) and another area in Argentina (Monje et al., 2015). Herein, we confirmed the identification of this agent based on an ompA partial sequence, which is highly polymorphic (Labruna et al., 2004). On the other hand, the $g / t A$ gene is highly conserved among various rickettsiae of the spotted fever group, which explains our overall BLAST results for this gene. Indeed, our molecular results on ticks infesting capybaras corroborate the serological status of these animals, i.e., $39.6 \%$ with $R$. bellii as the PAIHR, and $3.8 \%$ with $R$. parkeri as PAIHR.

While the present study's capybaras were also infested by $A$. sculptum, we found no molecular evidence of rickettsial infection in this tick species. This result is corroborated by several previous studies from BSF-nonendemic areas of the state of São Paulo, where no rickettsial agents were detected in A. sculptum, in contrast to a higher prevalence of $R$. bellii among A. dubitatum from the same areas (Sangioni et al., 2005; Horta et al., 2007; Pacheco et al., 2009).

While 25 A. dubitatum ticks yielded amplicon by the $R$. bellii-specific PCR assay, none of these samples yielded amplicon by the PCR assay targeting a portion of the gltA gene of Rickettsia spp. Noteworthy, this result was 
confirmed independently in two laboratories of the authors of the present study, by using different sets of reagents, including the primers (data not shown). These contrasting results were unexpected, as the Rickettsia spp-gltA assay was previously shown to amplify $R$. bellii from several tick species, including $A$. dubitatum (Labruna et al., 2004; Pacheco et al., 2009; Szabó et al., 2013). One possible reason for such results could be that the $R$. bellii strain infecting the A. dubitatum population of the Federal District presents some unique polymorphism in the region of the gltA gene that corresponds to at least one of the primers used in the Rickettsia spp-gltA assay. In fact, the set of primers of the present Rickettsia spp-gltA assay, which was designed primarily for SFG rickettsiae (M.B. Labruna, personal communication), has some significant polymorphisms when aligned with $R$. bellii sequences from GenBank (Table 3). Thus, the sensitiveness of this genus level-PCR assay might oscillate for $R$. bellii, depending on reagents and equipment (inherent to each laboratory), cycling conditions, and strain polymorphism. For this reason, the adoption of $R$. bellii-more specific assays is highly recommended in such cases.

Table 3. Nucleotide sequence alignment for the regions of the Rickettsia bellii gltA gene corresponding to primers CS-78 and CS-323.

\begin{tabular}{|c|c|c|}
\hline R. bellii strain & Primer CS-78 (forward) & Primer CS-323 (reverse) \\
\hline (GenBank acc. no.) & $5^{\prime}-\mathbf{3}^{\prime}$ & $5^{\prime}-\mathbf{3}^{\prime}$ \\
\hline Primer sequence & GCAAGTATCGGTGAGGATGTAAT & GCTTCCTTAAA---ATTCAATAAATCAGGAT \\
\hline RML 369-C $\mathrm{C}^{\top}$ (CP000087) & ..........GC........... & .....T.....AAA .....GC .......... \\
\hline Mogi-A. dubitatum (MF154866) & Not available & ..........AAA .....GC .......... \\
\hline RB-CL-I. loricatus (KX137900) & Not available & .....T.....AAA.....G........... \\
\hline
\end{tabular}

A study on the experimental infection of $R$. rickettsii in a $R$. bellii-infected population of $A$. dubitatum showed that $R$. bellii-infected ticks were unable to sustain $R$. rickettsii infections for consecutive generations (Sakai et al., 2014). Also, while the transovarian transmission of $R$. rickettsii was inefficient in all tested ticks, $100 \%$ of the same ticks performed transovarian transmission to $R$. bellii. This finding reinforces that the primary infection of Rickettsia species might prevent the transovarian transmission of a second species, which suppresses or cancels species from the tick population (Macaluso et al., 2002; Sakai et al., 2014). Our molecular results in A. dubitatum and also serological evidence of exposure of capybaras to $R$. bellii may suggest the inability of $R$. rickettsii to become established in the tick populations of the Federal District.

A small number of ticks classified as A. sculptum (29\%) was found in the present study. The species $A$. sculptum is considered the primary vector of $R$. rickettsii in Brazil (Costa et al., 2019). The predominance of the A. dubitatum in relation to $A$. sculptum observed in this work is also compatible with non-endemic areas for BSF, according to an epidemiological study published by Luz et al. (2019), who observed contrast between the predominant species in the tick populations in endemic and non-endemic areas, with the non-endemic being characterized by approximately $60 \%$ of $A$. dubitatum and endemic areas by approximately $90 \%$ of $A$. sculptum. These data can be related to what constitutes the Federal District as a non-endemic area for BSF.

\section{Acknowledgements}

The authors thank Coordenação de Aperfeiçoamento de Pessoal de Nível Superior - Brasil (CAPES) and Decanato de Pesquisa e Inovação da Universidade de Brasilia for their support in developing this work through a research grant. We would also like to thank the Brazilian Zoo Foundation (Fundação Jardim Zoológico de Brasília - FJZB) for the support during the construction of the containment cages and technical assistance.

\section{References}

Arouca ME, Miranda LB, Lopes RS, Takahira RK, Kohayagawa A, Ciarlini PC, et al. Valores hematológicos de capivaras (Hydrochoerus hydrochaeris) criadas em cativeiro no município de Botucatu, SP. Cienc Rural 2000; 30(5): 813-817. http://dx.doi.org/10.1590/ S0103-84782000000500012.

Barros-Battesti DM, Arzua M, Bechara GH. Carrapatos de importância médico-veterinária da região neotropical: um guia ilustrado para identificação de espécies. São Paulo: Butantan; 2006. 
Birkenheuer AJ, Levy MG, Breitschwerdt EB. Development and evaluation of a semi-nested PCR for detection and differentiation of Babesia gibsoni Asian Genotype) and B. canis DNA in Canine Blood Samples. J Clin Microbiol 2017; 41(9): 4172-4177. http:// dx.doi.org/10.1128/JCM.41.9.4172-4177.2003. PMid:12958243.

Brasil. Ministério da Saúde. Casos confirmados de Febre Maculosa. Brasil, Grandes Regiões e Unidades Federais. 2000 a 2019 [online]. Brasília: Ministério da Saúde; 2019a [cited 2019 Jun 13]. Avaliable from: https://www.saude.gov.br/images/pdf/2019/junho/14/ Casos-de-Febre-Maculosa.pdf

Brasil. Ministério da Saúde. Óbitos de Febre Maculosa. Brasil, Grandes Regiões e Unidades Federais. 2000 a 2019 [online]. Brasília: Ministério da Saúde; 2019b [cited 2019 Jun 13]. Avaliable from: https://www.saude.gov.br/images/pdf/2019/junho/14/ Obitos-por-febre-maculosa.pdf

Brites-Neto J, Brasil J, Takeda GACG, Guillen AC, Labruna MB, Pinter A. Diferenciação morfométrica entre larvas de Amblyomma sculptum Berlese, 1888 e Amblyomma dubitatum Neumann, 1899. Arq Bras Med Vet Zootec 2018; 70(5): 1521-1528. http://dx.doi. org/10.1590/1678-4162-9774.

Costa FB, Gerardi M, Binder LC, Benatti HR, Serpa MCA, Lopes B, et al. Rickettsia rickettsii (Rickettsiales: Rickettsiaceae) infecting Amblyomma sculptum (Acari: Ixodidae) ticks and capybaras in a Brazilian spotted fever-endemic area of Brazil. J Med Entomol 2019; 57(1): 308-311. http://dx.doi.org/10.1093/jme/tjz141. PMid:31504641.

Darby AC, Cho NH, Fuxelius HH, Westberg J, Andersson SGE. Intracellular pathogens go extreme: genome evolution in the Rickettsiales. Trends Genet 2007; 23(10): 511-520. http://dx.doi.org/10.1016/j.tig.2007.08.002. PMid:17822801.

Eremeeva ME, Bosserman EA, Demma LJ, Zambrano ML, Blau DM, Dasch GA. Isolation and identification of Rickettsia massiliae from Rhipicephalus sanguineus ticks collected in Arizona. Appl Environ Microbio/ 2006; 72(8): 5569-5577. http://dx.doi.org/10.1128/ AEM.00122-06. PMid:16885311.

G1. Distrito Federal. Secretaria de Saúde apura 'ataque' de carrapatos a visitantes do Zoo do DF [online]. Brasília: G1; 2017 [cited 2017 Jun 3]. Available from: https://g1.globo.com/distrito-federal/noticia/secretaria-de-saude-apura-ataque-de-carrapatos-avisitantes-do-zoo-do-df.ghtml

Halos L, Jamal T, Vial L, Maillard R, Suau A, Le Menach A, et al. Determination of an efficient and reliable method for DNA extraction from ticks. Vet Res 2004; 35(6): 709-713. http://dx.doi.org/10.1051/vetres:2004038. PMid:15535960.

Hecht JA, Allerdice ME, Krawczak FS, Labruna MB, Paddock CD, Karpathy SE. Development of a Rickettsia bellii-specific TaqMan assay targeting the citrate synthase gene.J Med Entomo/ 2016; 53(6): 1492-1495. http://dx.doi.org/10.1093/jme/tjw111. PMid:27473178.

Horta MC, Labruna MB, Pinter A, Linardi PM, Schumaker TTS. Rickettsia infection in five areas of the state of São Paulo, Brazil. Mem Inst Oswaldo Cruz 2007; 102(7): 793-801. http://dx.doi.org/10.1590/S0074-02762007000700003. PMid:18094887.

Horta MC, Vianna MCB, Mafra CL, Schumaker TTS, Walker DH, Galvão MAM, et al. Prevalence of antibodies to spotted fever group rickettsiae in humans and domestic animals in a Brazilian spotted fever-endemic area in the state of São Paulo, Brazil: serologic evidence for infection by Rickettsia rickettsii and another spotted fever group Rickettsia. Am J Trop Med Hyg 2004; 71(1): 93-97. http://dx.doi.org/10.4269/ajtmh.2004.71.93. PMid:15238696.

La Scola B, Raoult D. Laboratory diagnosis of Rickettsioses: current approaches todiagnosis of old and new Rickettsial diseases. J Clin Microbiol 1997; 35(11): 2715-2727. http://dx.doi.org/10.1128/JCM.35.11.2715-2727.1997. PMid:9350721.

Labruna MB, Pacheco RC, Ataliba AC, Szabó MPJ. Human parasitism by the capybara tick, Amblyomma dubitatum (Acari: ixodidae). Entomol News 2007; 118(1): 77-80. http://dx.doi.org/10.3157/0013-872X(2007)118[77:HPBTCT]2.0.CO;2.

Labruna MB, Whitworth T, Horta MC, Bouyer DH, McBride JW, Pinter A, et al. Rickettsia species infecting Amblyomma cooperi ticks from an area in the state of São Paulo, Brazil, where Brazilian spotted fever is endemic.J Clin Microbio/ 2004; 42(1): 90-98. http:// dx.doi.org/10.1128/JCM.42.1.90-98.2004. PMid:14715737.

Levin ML, Snellgrove AN, Zemtsova GE. Comparative value of blood and skin samples for diagnosis of spotted fever group rickettsial infection in model animals. Ticks Tick Borne Dis 2016; 7(5): 1029-1034. http://dx.doi.org/10.1016/j.ttbdis.2016.05.011. PMid:27282078.

Luz HR, Costa FB, Benatti HR, Ramos VN, Serpa MCA, Martins TF, et al. Epidemiology of capybara-associated Brazilian spotted fever. PLoS Neg/ Trop Dis 2019; 13(9): e0007734. http://dx.doi.org/10.1371/journal.pntd.0007734. PMid:31490924.

Macaluso KR, Sonenshine DE, Ceraul SM, Azad AF. Rickettsial infection in Dermacentor variabilis (Acari: Ixodidae) inhibits transovarial transmission of a second Rickettsia. J Med Entomol 2002; 39(6): 809-813. http://dx.doi.org/10.1603/0022-258539.6.809. PMid:12495176.

Madella DA, Rodrigues Neto EJ, Felisberto ME, Souza CED. Valores hematológicos de capivaras (Hydrochoerus hydrochaeris) Rodentia:Hydrochoeridae) de vida livre na região de Campinas-SP. Cienc Rural 2006; 36(4): 1321-1324. http://dx.doi.org/10.1590/ S0103-84782006000400046. 
Martins TF, Barbieri AR, Costa FB, Terassini FA, Camargo LM, Peterka CRC, et al. Geographical distribution of Amblyomma cajennense (sensu lato) ticks (Parasitiformes: Ixodidae) in Brazil, with description of the nymph of $A$. cajennense (sensu stricto). Parasit Vectors 2016; 9: 186. http://dx.doi.org/10.1186/s13071-016-1460-2. PMid:27036324.

Martins TF, Onofrio VC, Barros-Battesti DM, Labruna MB. Nymphs of the genus Amblyomma (Acari: Ixodidae) of Brazil: descriptions, redescriptions, and identification key. Ticks Tick Borne Dis 2010; 1(2): 75-99. http://dx.doi.org/10.1016/j.ttbdis.2010.03.002. PMid:21771514.

Medeiros B. Crianças vão ao Zoo do DF e voltam para casa infestadas de carrapatos [online]. Brasília: Metrópoles; 2018 [cited 2018 Jul 13]. Available from: https://www.metropoles.com/distrito-federal/criancas-vao-ao-zoo-do-df-e-voltam-para-casa-infestadasde-carrapatos

Monje LD, Nava S, Eberhardt AT, Correa Al, Guglielmone AA, Beldomenico PM. Molecular Detection of the Human Pathogenic Rickettsia sp. Strain Atlantic Rainforest in Amblyomma dubitatum Ticks from Argentina. Vector Borne Zoonotic Dis 2015; 15(2): 167169. http://dx.doi.org/10.1089/vbz.2014.1741. PMid:25700048.

Ojasti J. Estudio Biologico del Chigüire o Capibara. Caracas, Venezuela: FONAIAP; 1973

Pacheco RC, Horta MC, Moraes-Filho J, Ataliba AC, Pinter A, Labruna MB. Rickettsial infection in capybaras (Hydrochoerus hydrochaeris) from São Paulo, Brazil: serological evidence for infection by Rickettsia bellii and Rickettsia parkeri. Biomedica 2007; 27(3): 364-371. http://dx.doi.org/10.7705/biomedica.v27i3.199. PMid:18320102.

Pacheco RC, Horta MC, Pinter A, Moraes-Filho J, Martins TF, Nardi MS, et al. Survey of Rickettsia spp in the ticks Amblyomma cajennense and Amblyomma dubitatum in the State of São Paulo. Rev Soc Bras Med Trop 2009; 42(3): 351-353. http://dx.doi. org/10.1590/S0037-86822009000300023. PMid:19684990.

Paddock CD, Sumner JW, Comer JA, Zaki SR, Goldsmith CS, Goddard J, et al. Rickettsia parkeri: a newly recognized cause of spotted fever rickettsiosis in the united states. Clin Infect Dis 2004; 38(6): 805-811. http://dx.doi.org/10.1086/381894. PMid:14999622.

Parola P, Paddock CD, Raoult D. Tick-Borne Rickettsioses around the World: emerging diseases challenging old concepts. Clin Microbiol Rev 2005; 18(4): 719-756. http://dx.doi.org/10.1128/CMR.18.4.719-756.2005. PMid:16223955.

Sakai RK, Costa FB, Ueno TEH, Ramirez DG, Soares JF, Fonseca AH, et al. Experimental infection with Rickettsia rickettsii in an Amblyomma dubitatum tick colony, naturally infected by Rickettsia bellii. Ticks Tick Borne Dis 2014; 5(6): 917-923. http://dx.doi. org/10.1016/j.ttbdis.2014.07.003. PMid:25108783.

Sangioni LA, Horta MC, Vianna MCB, Gennari SM, Soares RM, Galvão MAM, et al. Rickettsial infection in animals and Brazilian spotted fever endemicity. Emerg Infect Dis 2005; 11(2): 265-270. http://dx.doi.org/10.3201/eid1102.040656. PMid:15752445.

Silveira I, Pacheco RC, Szabó MPJ, Ramos HGC, Labruna MB. Rickettsia parkeri in Brazil. Emerg Infect Dis 2007; 13(7): 1111-1113. http://dx.doi.org/10.3201/eid1307.061397. PMid:18214195.

Sousa KCM, Calchi AC, Herrera HM, Dumler JS, Barros-Battesti DM, Machado RZ, et al. Anaplasmataceae agents among wild mammals and ectoparasites in Brazil. Epidemiol Infect 2017; 145(16): 3424-3437. http://dx.doi.org/10.1017/S095026881700245X. PMid:29103397.

Souza CE, Moraes-Filho J, Ogrzewalska M, Uchoa FC, Horta MC, Souza SSL, et al. Experimental infection of capybaras Hydrochoerus hydrochaeris by Rickettsia rickettsii and evaluation of the transmission of the infection to ticks Amblyomma cajennense. Vet Parasitol 2009; 161(1-2): 116-121. http://dx.doi.org/10.1016/j.vetpar.2008.12.010. PMid:19147293.

Szabó MP, Nieri-Bastos FA, Spolidorio MG, Martins TF, Barbieri AM, Labruna MB. In vitro isolation from Amblyomma ovale (Acari: Ixodidae) and ecological aspects of the Atlantic rainforest Rickettsia, the causative agent of a novel spotted fever rickettsiosis in Brazil. Parasitology 2013; 140(6): 719-728. http://dx.doi.org/10.1017/S0031182012002065. PMid:23363571.

Venzal JM, Portillo A, Estrada-Peña A, Castro O, Cabrera PA, Oteo JA. Rickettsia parkeri in Amblyomma triste from Uruguay. Emerg Infect Dis 2004; 10(8): 1493-1495. http://dx.doi.org/10.3201/eid1008.030999. PMid:15496258.

Weiser G. Laboratory technology for veterinary medicine. In: Thrall MA, Wiser G, Allison RW, Campbell TW. Veterinary hematology and clinical chemistry. 2nd ed. Ames, IA, USA: Wiley-Blackwell; 2012. p. 3-33. 